\title{
A padkás erózió folyamata és mérése az Alföldön
}

\author{
RAKONCZAI JÁNOS és KOVÁCS FERENC
}

SzTE Természeti Földrajzi és Geoinformatikai Tanszék, Szeged

Annak ellenére, hogy a padkás erózióban érintett területek kiterjedése nagy és tájképi jelentőségű hazánkban (alföldi nemzeti parkjaink területein szinte általános), kevés tanulmány foglalkozik a sajátos felszínformák átfogó geomorfológiai értékelésével (STRÖMPL, 1931; TREITZ, 1934; DÖVÉNYI et al., 1977; TÓTH, 2003).

A technológiai fejlődésnek köszönhetően a terepi mérések, a fotogrammetriai technikák pontosságának jelentős léptékủ növekedésével a recens geomorfológiai folyamatok feltárásában a rövidebb időszakok változásai is kimutathatóak. E lehetőséget felhasználva egy korábban alig mérhető jelenség, a padkás erózió sajátosságainak feltárásába kezdtünk, melynek értékelése lehetőséget adhat a síkvidéki erózió mértékének a meghatározásához. A több mint 100 évet felölelő vizsgálat mérései alapján már értékelhető változások regisztrálhatóak.

\section{A padkás geomorfológia}

Az Alföld különleges morfológiájú padkás felszínei elsősorban a vízrendezések előtt rendszeresen elöntött vidékeken találhatók, de a formák megjelennek a tájrendezési munkálatokhoz kapcsolódva is. A jellemzően 10-30 cm magas formák főleg szikes területeken találhatóak, de ez - bár a talajszerkezet segíti kialakulásukat nem kizárólagos feltétele a padkás eróziónak.

Először az 1970-es években, a Szabadkígyósi pusztán találkoztunk a „szikpadka" probléma genetikai megoldatlanságával. A morfológiai és talajtani elemzéseink során (DÖVÉNYI et al., 1977) nyilvánvaló lett, hogy a nevezéktan pontosításra szorul, és sikerült megfelelő magyarázatot találni a mikroformák kialakulására is. Ekkor még a padkásodás jelenségét a szikes talajokhoz kötődőnek tartottuk, így megtartottuk a korábban használt elnevezéseket.

A sajátosan gazdag mikroformakincset formakomplexumokként lehet felfogni. A szikpadka a zárt szikes pusztai gyeppel borított, ép talajszelvényü - a denudációból kimaradt, eredeti felszínmagasságot mutató - térszínnek (hát, padkatető) különbözö lejtőszögü peremmel való leszakadása (padkaperem) egy alacsonyabb, elvékonyodó - a lehordódott talajt tartalmazó - térszínbe (sziklanka), majd a legmélyebb szikfokba (szikfenék, sziklapos). A szikpadka tehát a tető, a perem és a szik-

Postai cím: RAKONCZAI JÁNOS, Szegedi Tudományegyetem Természeti Földrajzi és Geoinformatikai Tanszék, 6701 Szeged, Pf. 653.E-mail: rjanos@earth.geo.u-szeged.hu 
lanka formaegyüttese, amely szorosan kapcsolódik a helyi erózióbázis szintjéhez. A sziki ér a kezdeti padkásodási folyamat haladását mutatja és a szikfenék terebélyesedése - a sziklaposok kialakulása - után a felesleges vizet szállítja el az erózióbázis felé (RAKONCZAI, 1986; TóTH, 2003). A lejtés irányába mozgó csapadékvíz mechanikai hatása mellett a csepperózió, a huzamosabb talajátázás esetén a víz oldó hatása (szik-töbör) és a nagyon vizes időszakban a hullámzás ereje is rombolhatja a felszínt (1-4. ábra).

A padkaperem sokszor szinte vonalszerüen jelenik meg, máskor pedig több méteres fokozatos átmenetet képez. Az eróziós felszínen feldarabolódott, változatos félsziget- és szigetszerủ mikroformák alakulnak ki. A folyamat során az oldható sók részben a mélybe szivárognak, illetve átmenetileg felszíni „,sóvirágzást” is okozhatnak. A szilárd kőzetszemcsék kisebb részben a szárazságok során képződő repedésekbe jutnak, de nagyobb részüket a mélyedésekben kialakuló sziki erek (3. ábra) vagy - a kiszáradt felszínről - a szelek szállítják el.

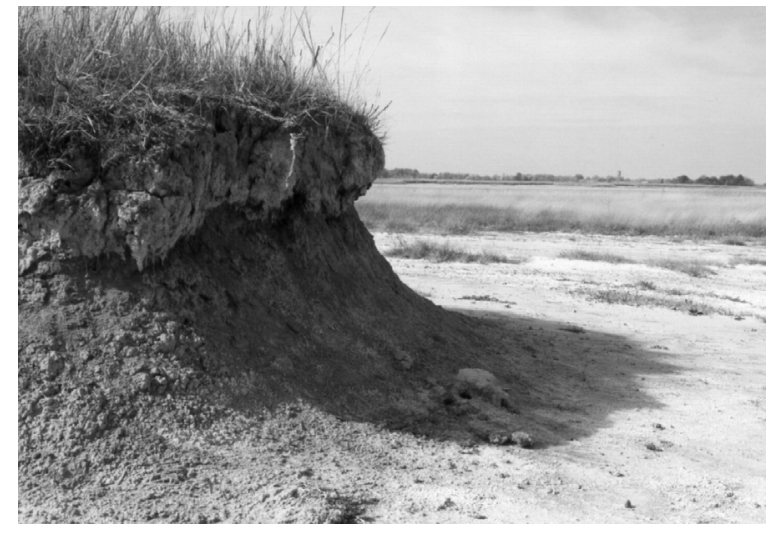

1. ábra

Meredek padkaperem Miklapusztán

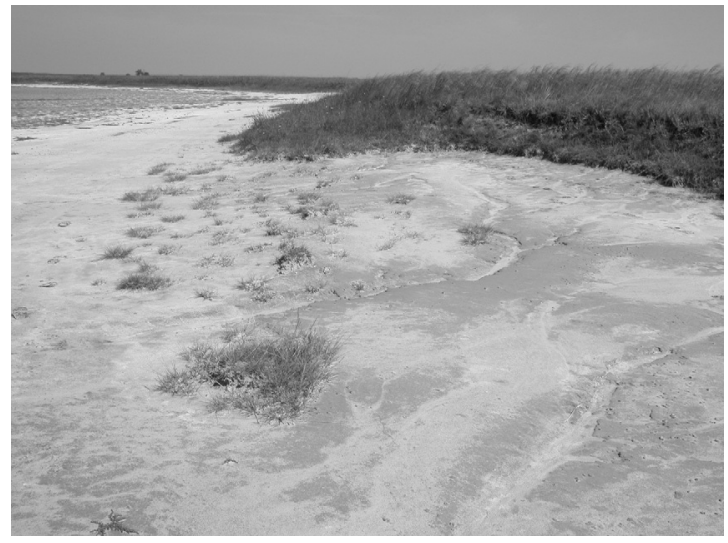

2. ábra

Sziklankába belesimuló szikpadka Miklapusztán 


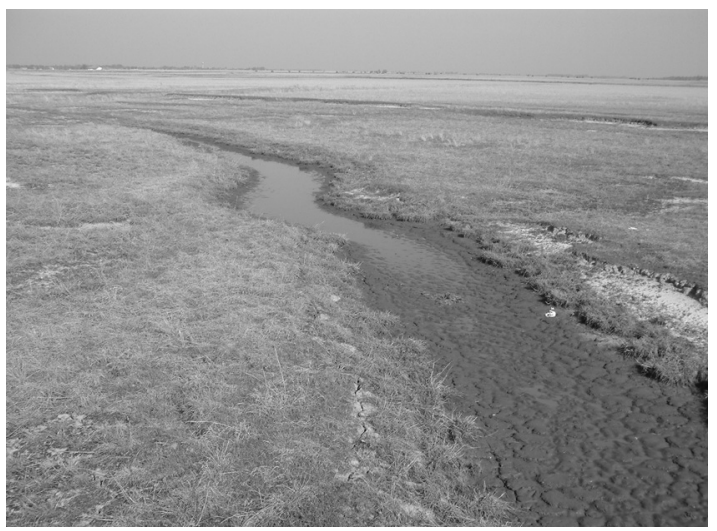

3. ábra

Sziki ér Tótkomlósnál

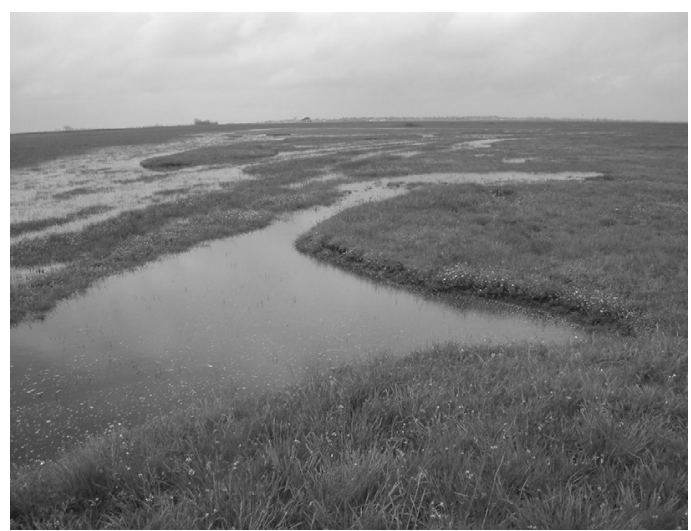

4. ábra

Az alámosás okozta erózió lehetősége vízbő időben Tótkomlásnál

\section{A padkapusztulás folyamata}

A padkás erózió folyamatát két fázisra célszerü választani: az egyik a padkásodás megindulása, a másik a kialakult padkás felszínek pusztulása.

A kutatók többsége egyetért abban, hogy a padkás erózió megjelenésének alapvető feltétele, hogy a síksági területeken - akár néhány cm-es - relatív magassági különbségek alakuljanak ki. Természetes körülmények között a táj folyóvízi feltöltődése során az egykori medermaradványok, vagy a folyóhátak okozzák a terep lejtését. A szikpadkák mintázata - egyes Duna-Tisza közei területeken - már az 1880as évek III. katonai térképein is utal a formák alluviális eredetére (és valószínüsíti, hogy azok elsődleges szikesedés eredményei). Az antropogén hatások, mint a területhasználat változása, a csatornák és árkok kiépítése, utak használata, a legeltetés miatti koncentrált állati taposás mind a lokális relief energia növekedését eredmé- 
nyezik, vagy a már padkás felszínt tagolják. Itt egy egyszeri mély keréknyom több évre járhatatlanná teheti az utat, így például a forgalom a térképen jelzettnél szélesebb sávban történik. A padkásodás teljesen sík vidékeken is elindulhat, a szárazság miatt keletkező nagyméretü talajrepedések nyomán. A további felszínfejlődést döntően a relatív magassági különbség és a talajszerkezet befolyásolja, de hatása van rá a növényzettel való fedettségnek is. ТóTH (2003) szerint a szikes felszínfejlődésnél iniciális, juvenilis, maturus és szenilis állapotok különböztethetők meg, melyeket az antropogén beavatkozások jelentősen befolyásolnak.

A padkás erózió tipikus színterei a határozott talajszerkezettel rendelkező szolonyeces szikesek. Itt jellemzően 10-30 cm-es padkák alakulnak ki, mégpedig döntően a talaj felső szintjének lepusztulása nyomán. A Hortobágyon végzett kutatások alapján TÓTH (2003) osztályozza is az ilyen jellegủ területen megfigyelhető eróziót: areális, lineáris, hátráló és antropogén típusokra. Megállapításai többékevésbé összhangban vannak kutatásainkkal, de nagyobb területen végzett vizsgálataink szerint további fontos típus is azonosítható. Ugyanakkor az antropogén eróziócsoport elkülönítésével több okból sem értünk egyet. A padkásodási folyamat az esetek nagyobb részében valamilyen antropogén beavatkozásra vezethető vissza (csak az eltelt hosszabb idő miatt a pontos ok nem határozható meg), másrészt az emberi beavatkozás nyomán megindult padkásodás besorolható a többi csoportba (pl. a csatornáknál inkább a hátráló, a keréknyom hatására inkább a lineáris erózió okozza a padkásodást). Ezek figyelembevételével a padkás erózió négy fontos típusát különíthetjük el az Alföldön.

a) Hátráló erózió. Tapasztalatok alapján ez nevezhető a legjellemzőbb típusnak. A padka peremén, egy szabálytalan - döntően növényzetmentes - vonal mentén folyamatos talajpusztulás figyelhető meg (1. ábra). A folyamat során a talaj szinte fizikai összetevöire esik szét, és úgy szállítódik el. A hátráló erózió alapesetében szolonyeceken a talaj A-szintje lepusztul, s így a felszínre került nagy sótartalmú szinten csak sókedvelö növények élnek meg. Ha az erózió folyamata lelassul, a padkaperem oly mértékben kiszélesedhet, hogy a padkásodás nyomát csak a talajok sótartalmának alakulásában, illetve ennek nyomán a vegetáció változásában fedezhetjük fel, a morfológiában már alig (RAKONCZAI, 1986).

b) Leszakadásos erózió. Jelentős relatív magassági különbségek esetén kialakuló látványos, szakaszokra jól bontható típus. A jellemzően 60-100 cm-es (akár ennél is magasabb) padkák - a vizek alámosó tevékenysége nyomán - egyszerre akár tíz métert is meghaladó hosszban - a rajtuk levő növényzettel együtt leszakadnak (5. ábra). Ilyenkor a több $\mathrm{dm}^{3}$-es talajtömbök csak egy későbbi fázisban esnek szét szemcsékre. A helyzetéböl elkerült talajdarab változó kémiai tulajdonságai miatt a növényzet elöbb folyamatosan átalakul (fajösszetétele csökken és módosul), majd többnyire el is pusztul. Az eróziótípus jellemzö területe Miklapuszta (RAKONCZAI \& KovÁCS, 2000).

c) Lineáris erózió. Ez a típus leginkább a padkás felszínek feldarabolódásában fejti ki szerepét. Hatására a nagyobb hátak félsziget-, vagy szigetszerü formákká alakulnak, s a növekvő határvonaluk a pusztulásuk felgyorsulásával jár. Sokszor 


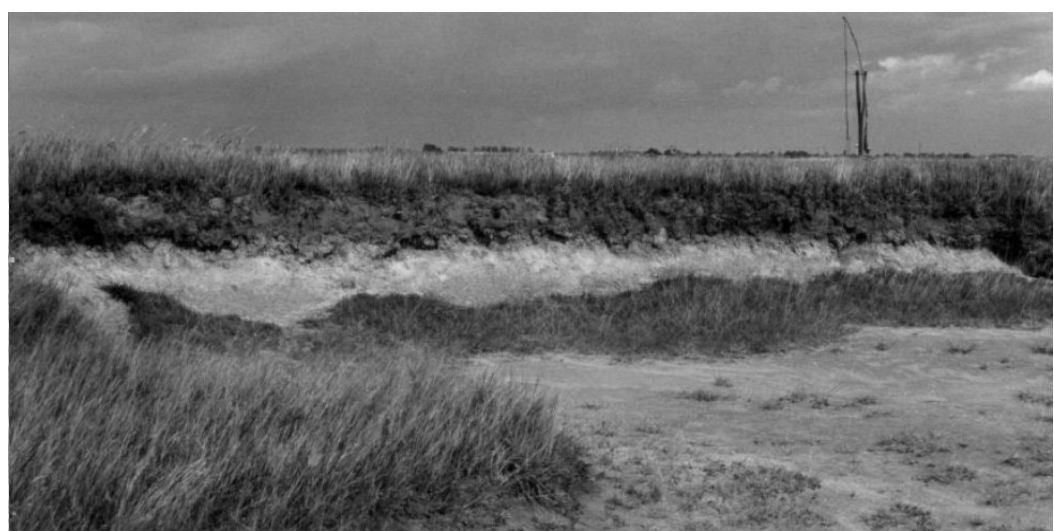

5. ábra

Leszakadásos erózió típusú szikpadka Miklapusztán

megtalálhatók az okok is, melyek elindítják a típus kialakulását (jármünyom, állatösvény). Az erózió kiteljesedése után ezekben a hosszanti formákban akár a vizek gyorsabb mozgását elősegítő sziki erek is kialakulhatnak.

d) Areális erózió. A padkák nem elsősorban a peremeik irányából pusztulnak, hanem egy lassú anyagelszállítódás nyomán felülröl alacsonyodnak. Ebben (még számunkra sem teljesen bizonyítottan) szerepe lehet a padkaperem begyepesedésének, illetve a padkatalaj lazább szerkezetének. A csökkenő magasságú padka morfológiailag belesimul a mélyebben fekvő környezetébe a sziklaposba, bár egy ideig a vegetációjával jól elkülöníthető az egykori mikroforma. A Szabadkígyósi pusztán 20-30 cm-es magasságú, 10-15 méteres átmérőjü padkás felszínek areális erózióra visszavezethető megsemmisülését sikerült rögzítenünk (6. ábra), mely folyamat mintegy 25 év alatt következett be.

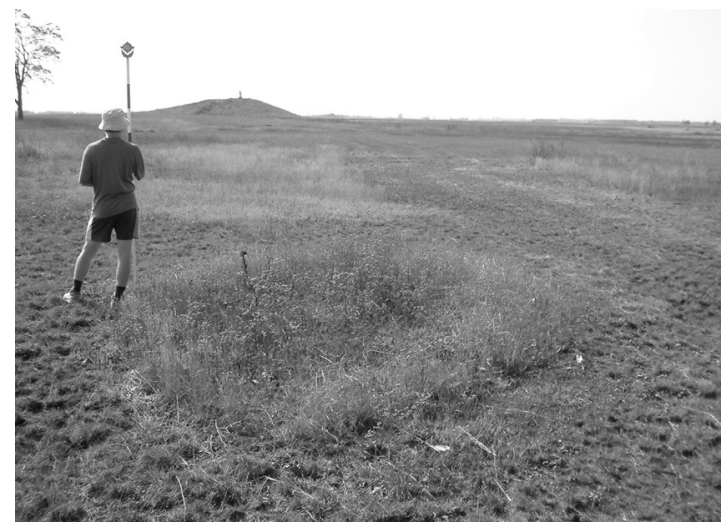

6. ábra

Begyepesedő egykori kopár szikes napjainkban a Szabadkígyósi pusztán. Az egykori szikpadkák helyét csak a vegetáció foltjai mutatják 


\section{A talajerózió és a földrajzi változások}

A homoktalajon kívül az Alföldön jelentős területeket elfoglaló, szélsőséges vízgazdálkodású szikesek a tájat ért változások érzékeny mutatói, ezért a talaj használata kulcsváltozónak tekinthető a globális változások vizsgálatában. A feltételezhető klimatikus változás magyarországi hatása az aridifikáció, az alföldi térség egyik legfenyegetöbb természetföldrajzi folyamategyüttese. A talaj és talajerózió olyan tájalkotó tényező és funkció, amelyek a mintaterületeinken betöltött szerepük és az alkalmazott módszereink miatt is alkalmasnak mutatkoztak a táji változásokat jelző felszíni folyamatok értékelésére.

A szikpadkák fejlődésében az utóbbi évtizedekben több tényező okozhatott változásokat. Elsősorban a szemiarid jelleg fokozódását (intenzívebb csapadék), a sztyeppesedési folyamatok megjelenését, illetve a fokozódó szárazság miatt ritkuló növénytakarót, valamint a tájrendezési munkálatokat említhetjük meg.

Igaz, hogy KERTÉSz és munkatársai (1998) szerint a Duna-Tisza köze területén még mindenhol elég folytonos a növénytakaró a defláció megakadályozásához, de a nagyüzemek megszüntével a korábban „rónásított” nagytáblákról egyre gyakrabban támad a homokvihar (SZATMÁRI, 2004). Az aszályhajlam gyakorisága fokozza a talajok repedezettségét és szerkezeti leromlását. A kiszáradt felszínről a szelek kisöpörhetik a sót. A sófelhalmozódással nő a szikesedés, megváltozhat a biológiai tevékenység (VÁRALlYAY, 1999). Az arid jelleg és felszín közeli talajvíz mellett a sófelhalmozódás egyre intenzívebbé válik, tehát szárazabb klíma esetén is lehet szikesedés. A mocsár és láprétek esetében ma is megfigyelhető, hogy a többletvízhatás csökkenése a talaj szikesedését vonja maga után, így az Alföld területének 1/4-e (1 milló ha) szikesedik (JÁRÓ, 2000), jóllehet a szikes és szikes altípusú talajok együttes aránya így is meghaladja Magyarország területének a 10\%-át (VÁRALLYAY, 1999). Az egyensúlyi talajvízszintnél mélyebb talajvíz esetén a lefelé irányuló vízmozgás következménye a kilúgozás, vagyis a negatív sómérleg. HARMATI (2000) felső-kiskunsági mérései alapján 1959-1995 között a talaj sótartalma a 0-10 és a 0$30 \mathrm{~cm}$-es rétegben is csökkent. A 0-40 cm-es talajréteg 34\%-os sócsökkenése 13,45 t/ha só kilúgozódását feltételezi 13 év alatt! Emellett a szódalúgosság hasonlóképpen, mindkét rétegben csökkent. A kilúgozás megfelelő pH-érték mellett nemcsak a $\mathrm{Na}^{+}$-ionok, hanem a $\mathrm{CaCO}_{3}$ mélybe mosódását is jelenti, ezért árulkodó lehet a karbonátmentes felső réteg vastagsága is. A szelvényben mélyebbre mosódott $\mathrm{CaCO}_{3}$ a megváltozott kémhatás miatt kicsapódik és a növényekre káros akkumulációs szintet hoz létre (NOVÁK, 2005). A szelvényen belüli só eloszlását befolyásolhatja a növényzet, mert a mély gyökérzet sekélyre való kicserélésével a felfelé szivárgó magas sótartalmú vizek már a felszín közelben hagyják hátra a sótartalmat. A sziktelenedés közvetlen bizonyítékaként fogható fel, hogy az egy-két évtizedes száraz periódust átélt szoloncsák talajok szódatartalma az egész szelvényből nagymértékben kilúgozódik és minden szintben egyenletes értéket vesz fel. A szoloncsák dinamika megakad és zártabb, kevésbé sótürő növénytakaró megtelepedésére nyílik lehetőség (KERTÉSZ et al., 2001).

SzÁsz (1997) szerint az Alföldön több helyen az arid területekre jellemző, mintegy 2 m-es mélységben megfigyelhető, az elmúlt évtizedekben állandósult száraz 
réteg helyezkedik el, amely elkülöníti a felső és alsó talajréteg vízforgalmát. A vízborította területekre jellemző glejes rétegek a talajban az egykori talajvízszintre utalnak és mint referenciafelületek mutatják a jelenkori talajfejlődést. SzABOLCS és JASSÓ (1961) szerint a folyószabályozások és lecsapolások óta a talajvíz a Kiskunságban 30-100 cm, Szeged környékén 10-100 cm-re van a glejes szint alatt. A sztyeppesedés folyamata ezután természetesnek vehetö! Az elemzéseket segítetik az egyre pontosabb adatbázisok (PÁSZTOR \& SZABÓ, 2006).

Az időjárási viszonyok néhány éves ingadozásának ismeretében csapadék esetén a só a szelvényben lefelé, míg a folyamatos szárazság esetén felfelé mozdulhat el (VÁRAllyAY, 1966). A Kiskunságban 2-3,5 t/ha volt az ingadozás 5 év alatt. A változékonyságra jellemző, hogy magas oldhatóságú sókoncentrációs (szoloncsák) területen a vízoldható sótartalom értékeinek ingadozása az éves minimumérték mennyiségének kétszeresét is meghaladta, és az akkumulációs szint néhány deciméteres eltolódása is jellemző volt (TóTH et al., 2003).

\section{Az erózió mérésének módszerei és lehetőségei}

A recens geomorfológiai változások mérése során gondot jelent, hogy a rövidebb idő alatt tapasztalt változások mennyiben általánosíthatók, valamint az is, hogy ezen változások kisebb értéke hogyan viszonyul mérési pontosságunkhoz. Ezért az értékelésünkhöz a mintaterület sajátosságai, az archív anyagok és a rendelkezésünkre álló mérési technikák függvényében több módszert összehangoltan alkalmaztunk. Ahol a domborzat ábrázolására a régi katonai felvételezések, térképek rendelkezésre álltak, a vizsgálatunkat hosszabb időszakra is kiterjesztettük. Összességében a padkás erózió folyamatának értékelése különböző években készült, eltérő típusú, méretarányú és ezáltal különböző pontosságú adatforrásokra alapuló változásvizsgálatok alapján történt. Az eredmények hosszabb kutatási időszak alapján születtek, de a változások mértékére vonatkozó adataink a 10-15 éves kontrollig csak információ jellegüként kezelendők.

Az 1970-es években kezdődő eróziós felmérésekre a tiszántúli szikeseken találunk példákat (DöVÉNYI et al., 1977; TóTH 2003). A mérések az 1990-es évektől a korszerübb eszközök (fotogrammetria, GPS, geodéziai mérőállomás) és feldolgozási technikák (GIS) bevonásával folytatódtak eltérő sajátosságú mintaterületeken (RAKONCZAI et al., 2004) (7. ábra).

A padkák hátrálásának mérésére három fö irányt jelöltünk ki:

- terepi adatfelvételezés, mérés GPS-el és digitális mérőállomással,

- mérések fotogrammetriai adatok alapján,

- régi és mai adatok együttes elemzése geoinformatikai módszerekkel.

A különböző időszakban és vetületi rendszerben rögzített adatok egységes rendszerbe transzformálása leginkább a nagy méretủ padkák változásának vizsgálatához használható. Az 1882. évi III. katonai felmérés, valamint az 1960-as és 1982-es, 1:10000 léptékủ topográfiai térkép felhasználásával készítettünk elemzést Miklapuszta területén. A katonai térkép EOV rendszerbe történő transzformációjánál 20 $40 \mathrm{~m}$-es pontosságot értünk el (1:25000 méretaránynál a jelenlegi állami térkép- 


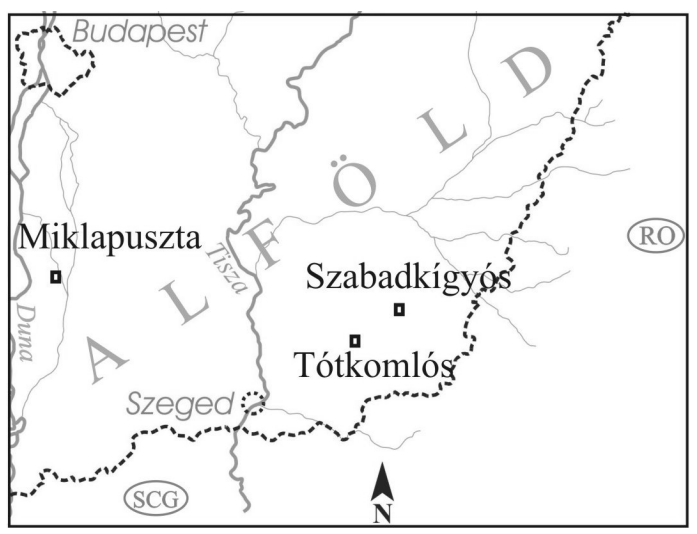

7. ábra

A padkás erózió mérésének mintaterületei az Alföldön

sorozatot tekintve is $5-8 \mathrm{~m}$-es horizontális pontossággal számolhatunk). Az egykori szikformák nagyon jól azonosíthatók a mai térképeken, de helyileg pontatlanul ábrázolták őket, ezért a transzformált katonai térképröl interpretált és vektorizált padkákat illeszteni kellett a mai határokhoz.

Az 1982. és 1960. évi térképeken a legtöbb esetben ugyanazok a padkahatárok találhatók! Ekkora lépték mellett már egy minimális térképi eltérés olyan valós padkavonal-változást mutatna, ami a terület egészét tekintve az adott 20 év alatt túlzásnak tünhet. Azt is biztosra vehetjük azonban, hogy az ember, vagy az állatok jelenléte miatt több helyen igenis történhetett méteres nagyságrendủ erózió, alakulhatott ki újabb padkás terület, amit néhány helyen meg is találhatunk. A terepbejárás és az 1967. évi CORONA müholdképek vizsgálata alapján kérdéses, hogy a térképeken miért csak egyes szikpadkákat határoltak le, mivel az ábrázoltakon kívül több hasonló méretű és jellegű forma is megfigyelhető.

A digitális topográfiai térképen a felbontás miatt megközelítőleg 1 méteres a pixelméret, vagyis - ha az alaptérkép nagyon pontos is - mi csak az ennél nagyobb változásokat tudnánk jegyezni. A térképsorozatra egyébként is a $3-5 \mathrm{~m}$-es horizontális pontosság jellemző. A felsorolt tényezők alapján a csak a térképekkel megvizsgált 100 éves hosszú időtartam eredményei alapvetően informáló jellegüek és elsősorban a müszeres mérések megalapozását szolgálják, de az eredmények irányadók is a ma jellemző erózió mértékének a megállapításához.

A fotogrammetriai adatok (a 2000. évi légifényképezési program képei) interpretációjánál - melyet Miklapuszta területén alkalmaztunk - a gyakorlatilag függöleges, lehetőleg növényzetmentes peremü szikpadkák megfigyelésére koncentráltunk, amelyeknél egyértelmü a padkaperem térképezése (1. ábra). A padkásodási folyamatban a perem alá is mosódhat, lezökkenhet, s a légifotón állandó padkaperemként értelmezzük a pusztuló felszínt. Hamis értékelést okoz, ha a magasabb részekről lehordódott anyag a sziklankán rakódik le, és a szikpadka nem hátrál, hanem látszólag nő. Problémát okozott a térképi és képi adatok korlátozott együttes 
használhatósága is. A vakszik és vegetáció kontrasztját kihasználva vektorizáltuk a képeken a padkahatárokat, majd terepi adataink alapján jelöltük ki a függőleges peremü nagy formákat, illetve a lehordódott talaj miatt felülnézettben „rejtett” eróziós területeket. E problémák a későbbiekben alkalmazott sztereo-képpár alapú domborzatmodell kiértékelésével kiküszöbölhetők (KOVÁCS et al., 2006).

A legpontosabb, terepi mérések (SOKKIA Set310 méröállomással és TOPCON Turbo-S II GPS müszerrel) cm-es pontosságú eredményt szolgáltatnak. A méróállomás a gyorsabb eljárás. A közelben lévő háromszögelési pontok segítségével mért terepi pontokból kiszerkesztett határvonalak adták a legpontosabb információkat a padkák kiterjedéséröl.

\section{A padkás erózió mértéke különböző típusterületeken}

\section{Szoloncsák szikes nagypadkás eróziója (Miklapuszta)}

A Duna egykori árterén fekvő szoloncsák-szikes Miklapuszta Európa egyik leglátványosabb padkás szikese. A padkák többségében fél méternél magasabbak, de nem egyszer meghaladják az egy métert is. A közel $300 \mathrm{~cm}$ szelvényvastagságú szoloncsák vastagsága miatt lassabb lehet a kilúgozódási folyamat.

A térképalapú vizsgálatokra lehatárolt, mintegy 700 ha-os mintaterületen az 1882-1982 közötti időszakban, a szikformák határvonalai közötti távolságoknál a több mint 100 méteres különbségek esetén a hátrálást nagynak és gyorsnak minősíthetjük (8. ábra, 1. táblázat). Az ebben az esetben kiszámított több mint $1 \mathrm{~m} / \mathrm{év}$-es változás még akkor is nagyon nagy, ha a bizonytalanság miatt ennek a töredékével számolnánk. Hasonlóan gyors eróziót állapítottunk meg ott, ahol 1960-1982 között mérhető különbség adódott. A jelentős hátrálással jellemezhető padkák a mintaterület délkeleti felén tömörülnek, jellemző kitettség az erózió irányultságánál nem állapítható meg.

Az 1882-es térképen jól azonosítható összefüggő padkahátak mai helyén található feldarabolódott formák 100 év alatt kerülhettek ilyen állapotba. Így az 1982-es topográfiai térképen magán is lehet következtetni a padkásodás mértékére. Ha megmérjük a XIX. században még egységes padkahátakon belül kialakult új padkaszigetek egymástól való távolságát és ezt a lineáris eróziós hatás miatt megfelezzük, akkor egy évszázad változását becsülhetjük meg. Ezekre az értékekre nem vonatkozik számos említett pontatlansági tényezö! Természetesen az 1960-1982 között mért különbségek is hasonló pontosságot adnak.

A 8. ábra „valószínüsíthetően nagy és gyors padkahátrálás” és „padkaszigetek elkülönülésének vonala" kategóriák helyszínein átlagosan 10-15 cm/év értéket állapíthatunk meg, de sok helyen számolhatunk 30, sőt akár 50-75 cm/év-es padkahátrálással. TÓTH (2003) hortobágyi mérései alapján a jobban erodálódó szoloncsákon nem elképzelhetetlen az ilyen mértékü változás.

Több esetben is megfigyelhető a paraméterek fejlödésének legintenzívebb változata; csökkenő terület mellett nő a padkaperem hossza (8. ábra: pl. 1., 4. és 7. számú szikpadka). Ezeket a padkahátakat csak a formájuk alapján is különösen sérülékenynek minősíthetjük, itt a talajdegradáció felgyorsulása várható. 


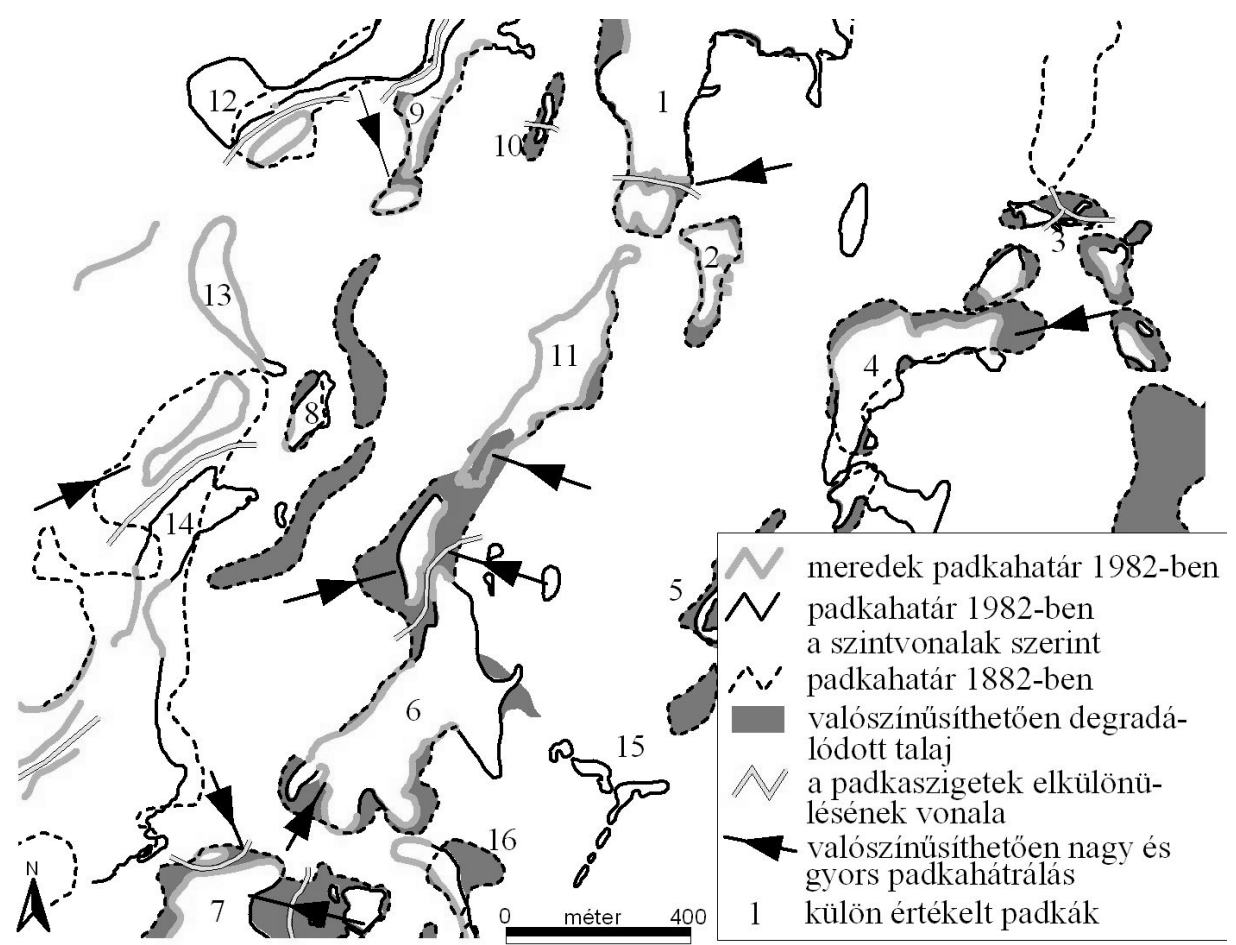

8. ábra

A szikpadkás felszínformálódás jellemzése Miklapusztán

A területi lepusztulás a III. katonai felméréshez viszonyítva az egyes padkákat nézve, átlagosan 40\%-os. A megvizsgált hátak alapján a XIX. század végén körülbelül 4,5 ha-os átlagméret mára alig 1,5 ha-ra csökkent, úgy, hogy eközben számuk megduplázódott (1. táblázat).

A fokozottan veszélyeztetett területeket jól kijelöli az utak, csatornák hálózatának sürüsödése, mely bizonyítja, hogy ma a tájhasználat az erózió talán legfóbb okozója. 1852-ben a terület 97\%-a a 0-40 m/ha-os útsürüségi kategóriákba tartozott, de 2000-ben már 40\%-os a 40-120 m/ha-os osztály részaránya (9. ábra). Ezt a hatást fokozza a közeli szántóföldek gépforgalma.

\section{1. táblázat}

Az erózió mértéke a 8. ábra egyes szikpadkáinál

\begin{tabular}{|c|c|c|c|}
\hline $\begin{array}{c}\text { Szikpadka } \\
\text { száma }\end{array}$ & $\begin{array}{c}\text { Eredeti terület, } \\
\text { ha }\end{array}$ & $\begin{array}{c}\text { 1982. évi terület, } \\
\text { ha }\end{array}$ & $\begin{array}{c}(4) \\
\text { Feltételezhető erózió, } \\
\mathrm{m}^{3} / \text { év }\end{array}$ \\
\hline 1 & 14,58 & 12,45 & $\mathrm{~kb} .100$ \\
3 & 4,80 & 1,90 & $>100$ \\
6 & 17,18 & 11,20 & $>200$ \\
7 & 10,90 & 5,20 & $>200$ \\
\hline
\end{tabular}




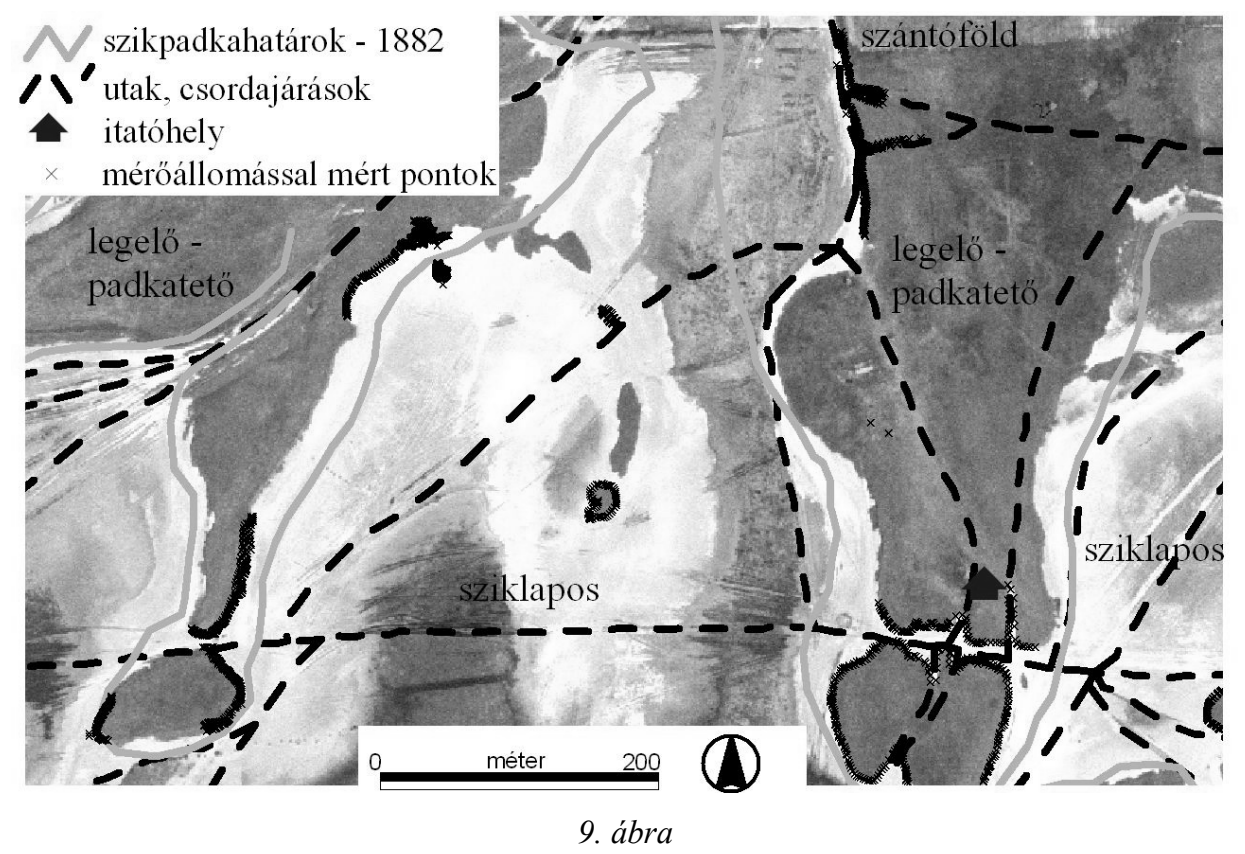

A tájhasználat és a padkás erózió kapcsolata (háttér: légifotó 2000)

Az 1980-2000 közötti időben a degradálódó felszíneket a mintaterületen is, valamint az azonosítható felsorolt padkahátakon belül is térben koncentráltan figyelhetjük meg (8. ábra, pl. 1., 4., 6., 9. és 14. számú padka). Az erózió mértéke e hátráló padkaperemeken átlagosan $20 \mathrm{~cm} / \mathrm{e} v$, míg a legnagyobb hátrálás a $0,75-1 \mathrm{~m} / \mathrm{e} v$ érték. A térképeknél tapasztaltakhoz hasonlóan az 1., 6. és 9. számú padkáknál átlag feletti a hátrálás mértéke. A térképen értékelt eróziós padkák közül azoknak csak a felén mértünk légifotó alapján talajpusztulást, de a képeken újabb gyorsan erodálódó peremeket is találtunk. Érdekes, hogy több esetben is a kisebb padkahátaknál interpretálhatók a magasabb értékek.

A 2000-2003 közötti különbségek kimutatását a térképen tapasztalt maximális (0,75-1 m/év) padkahátrálásra alapoztuk, amit a légifotók geometriai felbontása alapján megfigyelhetnénk. Az ennél kisebb erózió már nagy biztonsággal nem mutatható ki. Méréseink alapján az adott 3 év alatt nem tudtunk lepusztulási folyamatot lehatárolni. A peremek és sziklankák együttes felvételezésével és az EOTR magassági értékek mérésével a mérőállomás segítségével részletesen fel tudtuk térképezni a legmagasabb (jelenleg 1,05 m), illetve a legmeredekebb, vagyis a gyorsabban pusztuló szikformákat.

\section{Szolonyeces szikes padkás eróziója (Tótkomlós)}

A Tótkomlóstól DNy-ra levő pusztán jellemzően 10-20 cm-es padkák alakultak ki, döntően a talaj A-szintjének lepusztulásával. Az erózió elindításában a belvízel- 
vezetés céljából létesített csatornák, illetve az út menti árkok szerepe több helyen egyértelmünek látszik. A területen 1997 óta végzünk méréseket. A kezdeti időszakban GPS-szel rögzítettük a padkás térszínek határát, majd 2003-tól mérỏállomás segítségével végzünk összehasonlító méréseket.

A területen a hátráló erózió a jellemző, melynek értéke hat év alatt hozzávetőlegesen 0-15 cm. Mivel a GPS-es mérés során felvett pontok sürüsége elmaradt a kívánatostól, ezen eredményeink inkább csak tájékoztatóként értékelhetőek. Több szigetszerü mikroforma esetében az areális erózió is sejthető, azonban első mérésünkkor magassági adatokat nem rögzítettünk (ilyen kis magassági különbségekre a GPS nem volt alkalmas), így a formák alacsonyodását fényképek segítségével tudjuk bizonyítani.

\section{Szolonyeces szikes areális eróziója (Szabadkigyós)}

A Szabadkígyós és Kétegyháza közötti szikes pusztán már az 1970-es években készült részletes térkép teodolit és segédhálózat segítségével (10. ábra).

A mikroformákat határozott 20-30 cm-es padkaperemek határolták, és a padkatetőt, valamint a sziklapost karakterisztikusan eltérő növényzet borította. Amikor 2003 nyarán újabb térképezés céljából visszatértünk a területre, egy teljesen megváltozott tájat találtunk (6. ábra). A korábban vakszikkel és sótürő növényekkel borított sziklapos begyepesedett és jelentős méretü padkás formák „eltüntek”. Az egykor erodálódó és növénymentes padkaperemek annyira elsimultak, hogy határvonalukat nehéz lenne pontosan meghatározni. A 2000. év légi- és müholdfelvételei szerint is nagyon kevés a vakszikes folt (11. ábra).

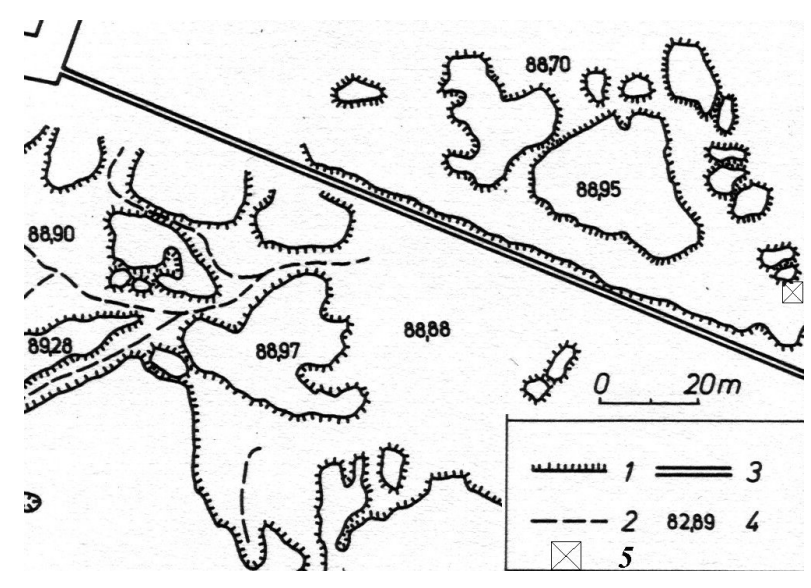

10. ábra

A mintaterület mikrodomborzata a Szabadkígyósi pusztán (DöVÉNYI et al., 1977) Jelmagyarázat: 1 . szikpadka és sziklapos határa; 2. sziki ér; 3. csatorna; 4. tengerszint feletti magasság, m; 5. a 6. ábra készítésének helye 


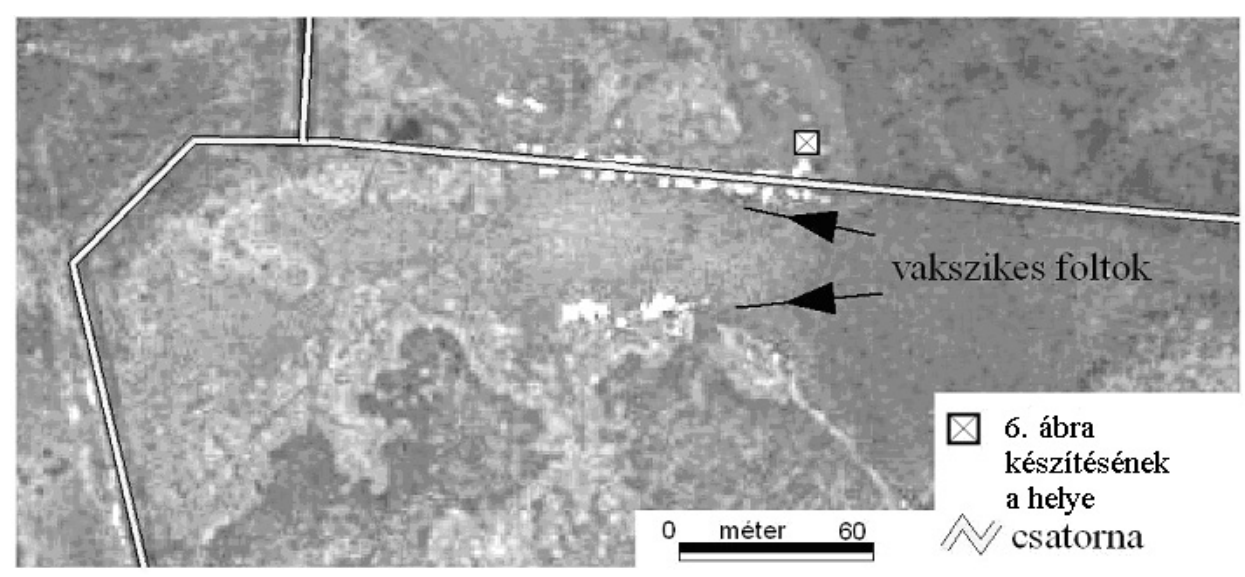

\section{1. ábra}

A szabadkígyósi mintaterület felszíne a 2000. évi légifotón

A területen negyedszázad alatt két fontos környezeti változás zajlott. Egyik az alföldi területeken általánosan megfigyelhető szárazodási folyamat „melléktermékeként" - a talajvízszint tartós csökkenése nyomán - a szikes talajok átalakulása, ami látványosan tükröződik a vegetáció átalakulásában, a másik a padkás mikroformák jelentős átalakulása. A változás azért is érdekes, mert a vízrendezéseknek és az egykori folyómedreknek köszönhetően a belvizes időkben még a megye délebbi részeiről is ide került a felesleges víz.

A leglátványosabb változást több olyan padka mutatta, amely 1977-ben még jól térképezhető volt, s ma csak eltérő növényzetük jelzi egykori formájukat, domborzati különbség nem. A padkák helyén, azok méretével közel megegyezö, helyenként sóvirágos (Limonium Gmelini) foltokat, üdébb vegetációjú gyepeket figyelhetünk meg. Ez arra utal, hogy a területen a korábbi hátráló erózió areálissá váltott (hátráló erózió esetén az eltérö talajminőségű foltok mérete az egykori padka méreténél kisebb lenne). Folyamatos mérések hiányában egyelöre nem tudjuk, hogy az erózió jellegének változása kapcsolatban van-e a szárazodási folyamattal.

\section{A folyamat következményei}

Kutatásaink alapján megállapítható, hogy a padkás erózió viszonylag gyors tájformáló tényezö, amely leginkább a gyep és legelő hasznosítású síksági területeken tapasztalható. Miután az erózió jellemzően cm-es (vagy $10 \mathrm{~cm}$-es) nagyságrendü, a változások már egy-két évtized alatt is tetemesek. A folyamatnak legalább két fontos következménye van. Egyrészt jelentös talajpusztulással jár, másrészt a tájképi és természetvédelmi jelentőségủ formák pusztulását okozza természetes körülmények között is, s azok megóvására a fokozott védettség mellett sincs mód. 
Jellemző folyamat a padkahátak fragmentációja. Miután a padkás erózió kialakulásához csak a „kezdeti lépést kell megtenni” (ezt sajnos már visszavonhatatlanul megtettük) és attól kezdve a felszínpusztulás nehezen megállítható, nem kell nagy jósnak lennünk ahhoz, hogy elörejelezzük ezen tájértékünk megállíthatatlan megsemmisülését. Mindez azt is jelzi, hogy a természetvédelem nem elégedhet meg csupán a passzív módszerekkel e területen.

Az éghajlati változásokhoz kapcsolódó talajvízszint-változások és az ezekkel összefüggő talaj- és vegetáció-módosulások nyomán a táji változások szerepet kaphatnak az eróziós formák átalakulásában. Méréseink szerint a talaj degradációjának átlagos üteme az elmúlt száz évben egyelöre nem változott.

Oknyomozó vizsgálatunk során felvetődik az a fontos kérdés, hogyan távozott el területünkről a több mint százezer $\mathrm{m}^{3}$ lepusztult anyag? Vannak pontos adatok arról, hogy a bepárlódó vízből korábban tetemes mennyiségü sziksót gyüjtöttek, ám a rendszeres vízelvezetés hiánya miatt leginkább a szél általi anyagelszállítást tartjuk a legvalószínübbnek.

A feltételezett talajeróziót a terepi és távérzékelési mérések együttes alkalmazásával csak úgy tudjuk bebizonyítani, vagy újraértékelni, ha a méróállomással, sztereo-képpárokkal 3-5 évenkénti méréssorozatokat tervezünk.

\section{Összefoglalás}

A magyarországi gyakorlat az Alföldet a legutóbbi időszakig nem számolta az erózió által veszélyeztetett területek közé. Ezt mutatja, hogy sem a térképeken (Magyarország Nemzeti Atlasza, 1989), sem statisztikákban (pl. KSH, 1986) nem szerepel erózió által veszélyeztetett alföldi terület. Tény, hogy itt a talajerózió mértéke jelentősen elmarad a dombsági területeken tapasztaltaktól, de a most bemutatandó kutatásaink is ráirányítják a figyelmet arra, hogy annak mértékét nem szabad lebecsülni. Erre a problémára jelent megoldást a padkás felszínek kutatása, mely értékelése lehetőséget ad a síkvidéki erózió mértékének a meghatározásához. A szárazodási folyamatokra érzékeny szikes talajoknál az utóbbi évtizedekben talajés vegetációs változások is valószínűsíthetők, melyek befolyásolják a sajátos formakincs fejlődését. A padkahátrálás mérésére három fő irányt jelöltünk ki, amikor a GPS-szel és digitális méróállomással végrehajtott terepi mérésekkel, légifelvételek vizsgálatával, valamint a régi és mai képi-térképi adatokat kezelő, elemző geoinformatikai módszerekkel foglalkoztunk.

A Duna menti szoloncsák szikes mintaterületünkön az 1882-2003 közötti idöszak alapján határoltuk le a nagy és a gyors talajerózióval jellemezhető helyszíneket. A pusztuló padkák esetében átlagosan 10-15 cm/év (akár 0,75-1 m/év) mértékü padkahátrálás állapítható meg. A területi lepusztulás a III. katonai felméréshez viszonyítva az egyes padkákat nézve átlagosan $40 \%$-os. A fokozódó tájhasználat miatt felgyorsulhat a padkahátrálás, amit jól bizonyítanak az úthálózat-sürüségi számítások és az aktuális légifotók. Napjainkban újabb és újabb helyeken erősödik az erózió. Méréseinkkel feltérképeztük a leggyorsabban pusztuló szikformákat. 
Tiszántúli szolonyec szikes mintaterületeinken a padkahátrálás mértéke kisebb: 0-15 cm/6 év, de 25 év terepi megfigyelései szerint a szárazodással együtt járó talaj- és a vegetációs változások rendkívül elörehaladottak.

Az éghajlati változásokhoz kapcsolódó táji változások is szerepet kaphatnak az eróziós formák átalakulásában. A 100 éves (hosszú), a 20 éves (rövidebb) és a 3 éves (legrövidebb) időközökben elemzett és további pontosításra szoruló vizsgálatok szerint a degradáció mértéke jelentősen nem változott. Tapasztalataink alapján a padkás talajerózió értékelésénél a méróállomással, sztereo-képpárokkal 3-évenként ismételt méréssorozatok adhatnak választ a felmérés jelenlegi pontatlanságaira.

Kulcsszavak: szikpadka, talajerózió, geoinformatika, tájváltozás

\section{Irodalom}

DöVÉNYI Z. et al., 1977. Természeti és antropogén folyamatok vizsgálata a kígyósi puszta területén. Békés megyei természetvédelmi évkönyv. 2. 43-72. Békéscsaba.

JÁRÓ Z., 2000. Az alföldi növénytakaró átalakulásának és átalakításának menete a vízrajzi munkálatok hatására. In: A XIX. századi folyószabályozások és ármentesítések földrajzi és ökológiai hatásai. (Szerk.: SoMOGYI S.) 190-204. MTA Földrajztudományi Kutatóintézet. Budapest.

HARMATI I., 2000. A vízrendezés hatása a Duna-völgy szikes talajaira. Agrokémia és Talajtan. 49.369-381.

KerTÉSz Á., PAPP S. \& SÁNTHA A., 2001. Az aridifikáció folyamatai a Duna-Tisza közén. Földrajzi Értesítő. 50. (1-4) 115-126.

KovÁCS F., SZATMÁRI J. \& RAKONCZAI J., 2006. Szikpadkás talajerózió értékelése az Alföldön térinformatikai módszerekkel. In: III. Magyar Földrajzi Konferencia tudományos közleményei. CD kiadvány.

Magyarország Nemzeti Atlasza, 1989. Magyar Tudományos Akadémia. Budapest.

NovÁK T. J., 2005. Tájváltozások értékelése szikes mintaterületen a talajok és a vegetáció egyes jellemzői alapján. PhD értekezés. Debrecen.

PÁszTOR, L. \& SZABÓ, J., 2006. Increasing accuracy of a spatio-temporal soil information system by digital soil mapping and field GIS. In.: Shaping the Future of Geographic Information Science in Europe. Proc. $9^{\text {th }}$ AGILE Conference. (Eds.: SuAREZ, J. \& MÁrkUS, B.) 104-110. College of Geoinformatics, University of West Hungary. Székesfehérvár.

RAKONCZAi J., 1986. A Szabadkígyósi Tájvédelmi Körzet talajviszonyai. Környezet- és Természetvédelmi Évkönyv. 6. 19-42.

RAKONCZAI, J. \& KovÁCS, F., 2000. Possibilities provided by GIS in the evaluation of landscape changes on plain territories. Acta Geographica Szegediensis. 37. 83-92.

RakoncZAi, J., Kovács, F. \& ZÁdori, A., 2004. Some examples of bench erosion from the Great Hungarian Plain. Acta Geographica Szegediensis. 38. 50-62.

STRÖMPL G., 1931. A szik geomorfológiája. Földrajzi Közlemények. 4-5. 62-74.

SZABOLCS I. \& JASSÓ F., 1961. A szikes talajok genetikai típusai és elterjedésük törvényszerűségei a Duna-Tisza közén. Agrokémia és Talajtan. 10. 173-195. 
SzATMÁRI J., 2004. Szélerózió-veszélyeztetettség értékelése a Duna-Tisza közén RWEQ modell alkalmazásával. In: A magyar földrajz kurrens eredményei. A II. Magyar Földrajzi Konferencia CD kötete. 1619-1627.

SzÁsz G., 1997. Az éghajlatváltozás és a fenntartható gazdaság kapcsolata a Nagyalföldön. Alföldi Tanulmányok. 16. 35-51.

Tо́тн Cs., 2003. A Hortobágy negyedidőszak végi felszínfejlődésének főbb természeti és antropogén vonásai. PhD értekezés. Debrecen.

Tóth T., KUTI L. \& FÜGEDI U., 2003. Havonkénti vizsgálatok a Zab-szék mellett. A tóvíz, talajvíz, talaj, növényzet időbeli változásai. Természetvédelmi Közlemények. 10. 191-205.

TREITZ P., 1934. Csonka-Magyarország sós és szikes talajai. In: A magyar szikesek. 177-204. Pátria. Budapest.

VÁrallyay Gy., 1966. A Duna-Tisza közi talajok sómérlegei, I. Agrokémia és Talajtan. 15. 423-445.

VÁRALlyAY GY., 1999. Szikesedési folyamatok a Kárpát-medencében. Agrokémia és Talajtan. 48. 399-416.

Érkezett: 2006. szeptember 11. 


\section{Process of Bench Erosion on the Great Hungarian Plain and Its Assessment}

\section{J. RAKONCZAI and F. KOVÁCS}

Department of Physical Geography and Geoinformatics, University of Szeged, Szeged (Hungary)

\section{Summary}

Until quite recently the area of the Great Hungarian Plain has not generally been considered not to be prone to erosion hazards. Areas in this region are not depicted on any maps displaying erosion hazards (The National Atlas of Hungary), and are not included in statistical evaluations. It is true that the degree of soil erosion on the Great Hungarian Plain is far below the value experienced in hilly areas. However, its potential should not be underestimated. This unique type of erosion, complemented by a gradual increase in aridity, may cause significant transformations in the soil and the environment.

Three main measurement methods were used:

- Field measurement with GPS and geodesic stations;

- Measurements based on photogrammetric data;

- GIS (combining data from different times and mapping systems into a uniform system).

On solonchak soil in the sample area the calculated average annual rate of bench retreat was high: $10-15 \mathrm{~cm} /$ year (maximum $0.75-1 \mathrm{~m} /$ year). The degree of erosion for individual benches was $40 \%$ on average compared to the data of the $3^{\text {rd }}$ military survey. Another characteristic feature was the dissection of bench ridges by roads, canals and flock paths leading to the formation of new isolated bench islands. The density of roads, canals and flock paths is increasing.

In study areas of the solonetz alkaline type the degree of erosion was approximately $0-15 \mathrm{~cm} / 6$ years. Here very rapid changes in the soil and vegetation were recorded because of the ongoing aridification.

The measurements indicate that the rate of bench erosion has not changed over the last century. Bench erosion should be evaluated by stereo-orthophoto images and field surveys with geodesic stations every 3 years.

Table 1. Extent of erosion at the bench margins of Fig. 8. (1) No. of sodic bench. (2) Original territory, ha. (3) Area in 1982, ha. (4) Probable erosion, $\mathrm{m}^{3} /$ year.

Fig. 1. Steep bench margin, Miklapuszta.

Fig. 2. Gently sloping bench margin, Miklapuszta.

Fig. 3. Alkaline veins, Tótkomlós.

Fig. 4. Possible erosion due to waves, Tótkomlós.

Fig. 5. Broken-off bench margin (Kiskunsági NP, Miklapuszta).

Fig 6. Former benches lowered by areal erosion (Körös Maros NP, Szabadkígyós).

Fig. 7. Study areas on the Great Hungarian Plain

Fig. 8. Rate of sodic bench retreat in the northern part of Miklapuszta (Legend: steep bench margin-1982; bench margin according to the contour line-1982; bench 
margin- $3^{\text {rd }}$ military mapping; surface probably eroded; separation lines of bench top islands; probable major rapid bench retreat; numbers refer to diagrams representing sodic benches).

Fig. 9. Effect of landscape utilization on bench erosion (background: aerial photo 2000).

Fig. 10. Micro-relief of the "puszta" at Szabadkígyós (Legend: 1: boundary between sodic bench and sodic plain; 2: natron stream; 3 : canal; 4: elevation above sea level (m); 5: location of Fig. 6.)

Fig. 11. Surface area of Szabadkígyós on the aerial photo 2000. (Legend: location of Fig. 6; channel). 